Altai State University

Acta Biologica Gibirica

Journal of Biology

Founded in 2015 www.asu.ru

ISSN 2412-1908

Acta Biologica Sibirica, 2017, 3(3), 39-46

\title{
Thermophilic facultative anaerobic bacteria of the genus Geobacillus from bottom sediments of Lake Baikal
}

\author{
T.A. Khanaeva1, O.N. Pavlova ${ }^{1,2}$, S.M. Chernitsyna ${ }^{1}$, I.A. Khalzov ${ }^{1}$, A.V. Khabuev ${ }^{1}$, \\ A.A. Nikonova ${ }^{1}$, A.S. Novikova ${ }^{1}$, T. I. Zemskaya ${ }^{1}$ \\ ${ }^{1}$ Limnological Institute of the Siberian Branch \\ of the Russian Academy of Sciences, Irkutsk, Russia \\ ${ }^{2}$ Irkutsk Scientific Center of the Siberian Branch \\ of the Russian Academy of Sciences, Irkutsk, Russia
}

tkhan@lin.irk.ru; pavlova@lin.irk.ru; sveta@lin.irk.ru; i_halz@lin.irk.ru; shok@lin.irk.ru; alenaxis@list.ru; linka@lin.irk.ru; tzema@lin.irk.ru

Pure culture of thermophilic facultative anaerobic microorganism was isolated from surface sediment of methane seepage Posolsk Bank. New strain Geobacillus sp. PB15/Grf7geo does not differ from the typical strains by morphological and physiological-biochemical properties. It is able to withstand of wide temperature range with optimum growth between $55-60{ }^{\circ} \mathrm{C}$. Chemoorganotroph. Phylogenetic analysis of the $16 \mathrm{~S}$ rRNA sequence of the strain showed $97 \%$ identity to cultivated strains of this genus. The strain forms a common clade with uncultivated representatives and does not cluster with sequences of cultivated strains within the genus Geobacillus in the phylogenetic tree. Strain Geobacillus sp. PB15/Grf7geo has been deposited to the collection of the VKM (=VKM B-3150 $\left.{ }^{\top}\right)$.

Key words: Lake Baikal; thermophilic bacteria; methane seepage; Posolsk Bank; Geobacillus sp.

\section{Термофильная факультативно анаэробная бактерия р. Geobacillus из донных осадков озера Байкал}

\author{
Т.А. Ханаева ${ }^{1}$, О.Н. Павлова ${ }^{1,2}$, С.М. Черницына ${ }^{1}$, И.А. Хальзов ${ }^{1}$, А.В. Хабуев ${ }^{1}$, \\ А.А. Никонова ${ }^{1}$, А.С. Новикова', Т.И. Земская ${ }^{1}$ \\ ${ }^{1}$ Лимнологический институт Сибирского отделения Российской академии наук, \\ Иркутск, Россия \\ ${ }^{2}$ Иркутский научный центр Сибирского отделения Российской академии наук, \\ Иркутск, Россия
}

tkhan@lin.irk.ru; pavlova@lin.irk.ru; sveta@lin.irk.ru; i halz@lin.irk.ru; shok@lin.irk.ru; alenaxis@list.ru; linka@lin.irk.ru; tzema@lin.irk.ru 
Из поверхностных осадков метанового сипа «Посольская Банка» (Южный Байкал) получена чистая культура термофильного, факультативно анаэробного микроорганизма. Новый штамм Geobacillus sp. PB15/Grf7geo по морфологическим и физиолого-биохимическим свойствам не отличается от типовых штаммов. Способен выдерживать широкий диапазон температур, с оптимумом роста 55-60 ${ }^{\circ} \mathrm{C}$. Хемоорганогетеротроф. Анализ структуры $16 \mathrm{~S}$ рРНК этого штамма показал, что он идентичен по структуре культивируемым штаммам на $97 \%$. На филогенетическом дереве штамм образует общую кладу с некультивируемыми формами и не кластеризуется с последовательностями культивируемых штаммов внутри рода Geobacillus. Штамм Geobacillus sp. PB15/Grf7geo депонирован в коллекцию ВКМ (=VKM В-3150').

Ключевые слова: озеро Байкал; термофильные бактерии; метановый сип; Посольская Банка; Geobacillus sp.

\section{Введение}

Термофильные прокариоты - особая группа микроорганизмов, развивающаяся при температурах свыше 60 ${ }^{\circ} \mathrm{C}$. Микробные сообщества высокотемпературных нефтяных месторождений, подземных водных резервуаров, глубинных горнодобывающих шахт, высокотемпературных горизонтов, находящихся под океанической корой в районах современной подводной вулканической активности, значительно отличаются друг от друга по составу, исходному энергетическому субстрату, основным микробиологическим процессам (Ghiorse, Wilson, 1988; Jimenez, 1990; Takai et al., 2001; Bonch-Osmolovskaya et al., 2003; Frank et al., 2016).

Озеро Байкал, донные осадки которого являются объектом исследования, не относится ни к одному из вышеперечисленных биоценозов. Стабильно низкие температуры глубоководных осадков озера Байкал (3.1-5.7 $\left.{ }^{\circ} \mathrm{C}\right)$ определяют развитие и функционирование психрофильного микробного сообщества, играющего важную роль в круговороте вещества и энергии (Namsaraev, Zemskaya, 2000). Расположение озера Байкал в тектонически активной зоне обуславливает наличие районов геологических аномалий, разгрузок газосодержащих флюидов, грязевых вулканов, залежей газовых гидратов. Минерализованные флюиды могут мигрировать вдоль проницаемых зон и появляться в поверхностных осадках оз. Байкал, приуроченных к тектоническим нарушениям. Очевидно, что вместе с углеводородсодержащими флюидами в поверхностные осадки из глубинной зоны могут поступать и термофильные микроорганизмы. Районом концентрации геологических аномалий является Посольский разлом, и в частности, граничащая с ним подводная возвышенность Посольская Банка, расположенная на границе Южной и Центральной котловин озера Байкал (Naudts et al., 2012).

Состав бактериального сообщества в донных осадках Посольской банки значительно отличается от таковых в других районах разгрузки углеводородсодержащих флюидов. В поверхностных осадках установлено присутствие хемолитотрофных, хемоавтотрофных и анаэробных органотрофных микроорганизмов, участвующих в циклах азота, углерода и серы. Особенности состава микробных сообществ в этом районе обеспечивается наличием особых путей миграции газосодержащих флюидных потоков с которыми в холодные поверхностные осадки могут поступать глубинные термофильные прокариоты (Naudts et al., 2012; Chernitsyna et al., 2016). Для подтверждения этой гипотезы мы провели поиск термофильных, анаэробных микроорганизмов в районе выхода газосодержащих флюидных потоков района метанового сипа «Посольская Банка». В настоящей работе дается характеристика термофильного, факультативно анаэробного штамма PB15/Grf7geo, отнесенного к Geobacillus sp., изолированного из низкотемпературного слоя донных осадков вышеуказанного района.

\section{Материалы и методы исследований}

объект исследования. Бактериальный штамм PB15/Grf7geо выделен из поверхностных донных осадков, отобранных в районе метанового сипа «Посольская Банка» с помощью коробчатого пробоотборника во время экспедиции в июле 2015 года. Глубина водной толщи в точке отбора - 478 метров. Пробы осадка отбирали с соблюдением стерильности.

Условия культивирования. Получение накопительных культур проводили во флаконах (120 мл), содержащих 30 мл модифицированной среды Видделя для пресноводных форм (Widdel, Back, 1992), которая содержит полный набор витаминов и дрожжевой экстракт (0.5 г/л). В качестве восстановителя использовали сульфид натрия (2.5 мМ). Этот же состав среды использовали для поддержания накопительных культур бактерий. Культивирование осуществляли в течение 30 суток, при температуре $60{ }^{\circ} \mathrm{C}$. В качестве контроля служили флаконы с незасеянной средой. Изолирование культуры Geobacillus вели путем последовательных пересевов с последующим выделением колоний на твердой среде того же состава с добавлением агара - 15 г/л.

Методы исследования физиологических и ростовых характеристик. Влияние солёности на рост штамма определяли, используя среду Видделя, добавляя соль (NaCl) в концентрации от 0 до 15 г/л при фоновом содержании $\mathrm{NaHCO}_{3} 1$ г/л. Определение температуры, оптимальной для роста штамма, проводили с использованием градиентного термостата Binder BD 53 в диапазоне температур от 30 до $100{ }^{\circ} \mathrm{C}$. Значения рН для 
Khanaeva, T.A. et al. (2017). Thermophilic facultative.... Acta Biologica Sibirica, 2017, 3(3), 39-46

роста штамма PB15/Grf7geо определяли на среде Видделя без хлорида натрия, выравнивали молярность по натрию с помощью бикарбоната натрия. Различные значения рН устанавливали 10 \% раствором соляной кислоты или 10 \% раствором едкого натрия. Результат снимали через 3 суток инкубации в термостате при $60{ }^{\circ} \mathrm{C}$. Способность к росту в анаэробных условиях проверена при культивировании во флаконах с бескислородной минеральной средой Видделя с добавлением $\mathrm{KNO}_{3}$ (1 г/л) в качестве акцептора электронов. В качестве газовой фазы использовали смесь газов $\mathrm{H}_{2}: \mathrm{CO}_{2}$ в соотношении 4:1. Питательные среды готовили, используя анаэробную технику Хангейта (Hungate, 1969). Исследование физиолого-биохимических характеристик штамма проводили при помощи методов, описанных ранее (Logan et al., 2009). Спектр углеводного питания выявляли с использованием диагностических сред Гисса. Органические кислоты, сахара или пептиды добавляли в концентрации 3 г/л, спирты - 5 мл/л. Посевы инкубировали при $60^{\circ} \mathrm{C}$. Все анализы проводили в 2-х повторностях.

Морфология бактерий исследована с помощью сканирующего электронного микроскопа Quanta 200 (FEI Company, США) с ускоряющим напряжением в 20 киловольт на базе ЦКП «Электронная микроскопия» Объединенного ЦКП «Ультрамикроанализ» Лимнологического института СО РАН. Суспензию клеток фиксировали 4 \% раствором параформальдегида в 0.066 М буфере Соренсена при комнатной температуре в течение ночи. Далее клетки отфильтровывали на поликарбонатные фильтры (диаметр пор 0.2 мкм) и проводили обезвоживание в серии растворов этанола (30\%, 50 \%, 70 \%, 96 \%, 100 \%) и ацетоне (100\%). Затем проводили сушку в критической точке на приборе CPD 030 Critical Point Dryer (BALZERS, Лихтенштейн). Фильтры были помещены на алюминиевые столики и напылены золотом на установке SCD 004 (BalzersUnion, Лихтенштейн).

Анализ Г+Ц состава. Выделение и очистку высокополимерной ДНК для определения Г+Ц состава проводили по ранее описанной методике (Marmur, 1961; Heats et al., 1986). Содержание Г+Ц в ДНК находили по температуре плавления комплекса, используя саморегистрирующий спектрофотометр PyeUnicum SP1800 со скоростью подогрева 0.5 град./мин. Плавление проводили в растворе 0.1 SSC. Нуклеотидный состав рассчитывали согласно формуле, описанной ранее (Owen et al., 1969).

Метод анализа жирных кислот. Анализ состава жирных кислот проводили на хромато-масс спектрометре «6890B GC System, 7000C GC/MS Triple Quad» (Agilent, CШA) с колонкой «Optima-17MS» (MACHEREY-NAGEL, Германия). Детектирование и идентификацию пиков метиловых эфиров жирных кислот проводили в режиме регистрации полного масс-спектра с помощью программного обеспечения «NIST Mass Spectral Search Program for the NIST/EPA/NIH Mass Spectral Library (Version 2.2)». Количественный анализ МЭжК проводили методом внутреннего стандарта, в качестве которого использовали стандартный раствор дидецилового эфира в н-гексане (C=2.6 мг/мл). Калибровку МЭЖК проводили с использованием стандартных растворов «Methylcis-4,7,10,13,16,19Docosahexaenoicester 10 mg/mlinheptane» (Supelco, CША) и «F.A.M.E. Mix, C4-C24, 100 mg, Nеat» с аттестованными концентрациями компонентов смеси (Supelco, CША). При количественном анализе использовали значения калибровочных коэффициентов, полученные для индивидуальных соединений МЭЖК, а также средние значения для групп МЭЖК: насыщенных и мононенасыщенных.

Выделение ДНК, амплификация гена 16S рPHK и секвенирование. Выделение ДНК штамма проводили по модифицированной методике ферментативного лизиса с последующей фенол-хлороформной экстракцией (Sambrook et al., 1989). Амплификацию ДНК проводили в следующем режиме: $94{ }^{\circ} \mathrm{C}-2^{\prime}\left(1\right.$ цикл); денатурация $94{ }^{\circ} \mathrm{C}$ - 45", отжиг - $52{ }^{\circ} \mathrm{C}-45$ ", элонгация - $72{ }^{\circ} \mathrm{C}-60^{\prime \prime}$ (30 циклов); финальная элонгация - $72{ }^{\circ} \mathrm{C}-10^{\prime}(1$ цикл). В работе были использованы праймеры, комплементарные наиболее консервативным участкам гена 16S pPHK: 27LAGAGTTTGATCMTGGCTCAG, 500L-CGTGCCAGCAGCCGCGGTAA, 1350R- GACGGGCGGTGTGTACAAG (Brosius J. et al., 1981, Denisova et al., 1999). Секвенирование проводили на геномном анализаторе ABI 3130XL Genetic Analyser («Applied Biosystems») с использованием реактива BigDye Terminator Kit v.3.1 (Applied Biosystems) в ЦКП «Геномика», Новосибирск. Последовательности, полученные в результате секвенирования, сравнивали с последовательностями из международного банка данных NCBI с помощью программы BLASTN (http://www.ncbi.nlm.nih.gov/blast). Структуры были проанализированы с использованием программы ClustalW V 1.4 (http://www.ebi.ac.uk/clustalw). Сравнение последовательностей и построение филогенетических древ осуществляли с помощью пакета программ MEGA 5.01 (http:// www.megafile.co) с использованием алгоритмов группирования «Neighbor-Joining», модели «Kimura-2-parameters». Статистическая достоверность ветвления оценивалась с помощью "bootstrap-анализа", с использованием соответствующей функции той же программы. Последовательность штамма PB15/Grf7geо депонирована в GenBank под регистрационным номером KY55292.

\section{Результаты и их обсуждение}

Чистая культура факультативно анаэробной термофильной бактерии (PB15/Grf7geо) получена при культивировании образца донных осадков, отобранных в экспедиции в июле 2015 года. Исследование фенотипических и физиолого-биохимических характеристик показало принадлежность штамма к роду Geobacillus.

Культуральные свойства. Морфология клеток штамма PB15/Grf7geо варьировала в зависимости от возраста культуры. В суточной культуре клетки представлены одиночными длинными прямыми или слегка изогнутыми палочками (рис. 1 а, б). Деление с образованием перетяжек (бинарное деление). 
Khanaeva, T.A. et al. (2017). Thermophilic facultative.... Acta Biologica Sibirica, 2017, 3(3), 39-46
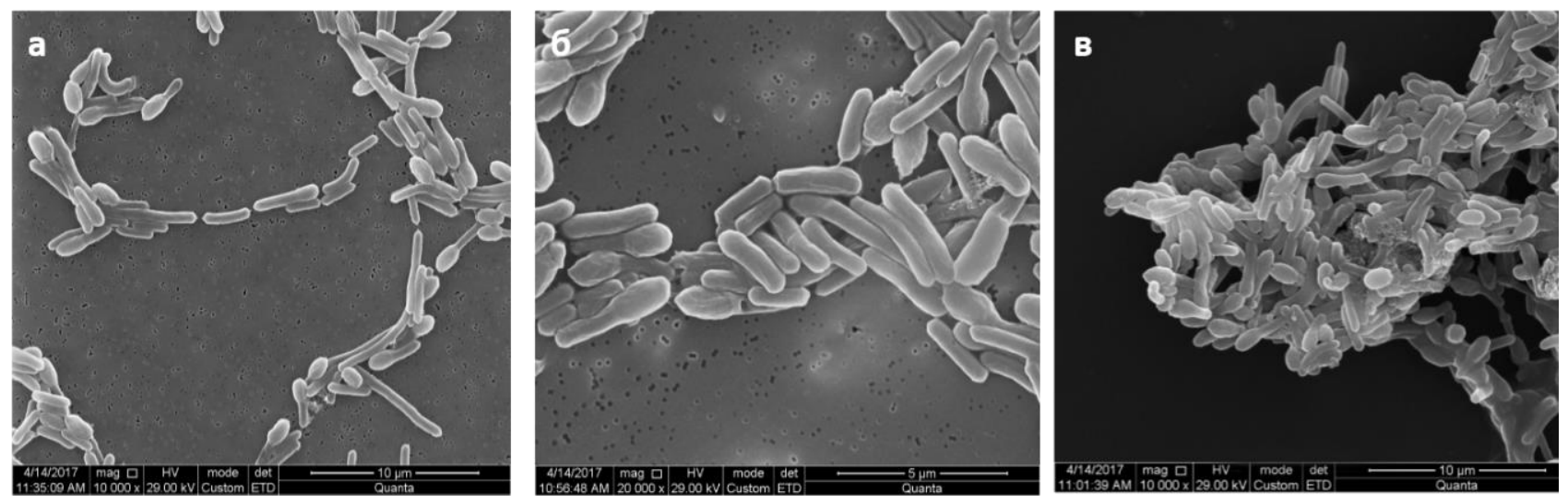

Рис. 1. Морфология клеток штамма PB15/Grf7geо на плотной питательной среде: суточная культура (а), трехсуточная культура (б, в). Масштаб: а, в - 10 мкм, 6 - 5 мкм

Микроорганизм подвижный за счет перитрихиально расположенных жгутиков. Клетки при окраске по Граму - положительные. Организм споровый. Спора овальная, локализована терминально. Спору клетка выбрасывает только на твердой среде (рис. 1 в). Культура терморезистентная. Споры выдерживают прогрев при $100{ }^{\circ} \mathrm{C}$ в течение 5 мин. Колонии штамма лишены пигмента, имеют округлую форму, плоские, непрозрачные, края неровные, консистенция плотная. При росте на жидкой среде наблюдается однородное помутнение среды с образованием рыхлого осадка в конце роста.

Физиологические свойства. Штамм термофильный, оптимум роста - 55-60 ${ }^{\circ} \mathrm{C}$. Верхняя граница роста - $80{ }^{\circ} \mathrm{C}$, нижняя - $46{ }^{\circ} \mathrm{C}$. Нейтрофил. При $\mathrm{pH} 5.0$ и рН 8.6 - рост отсутствовал. Область рН для роста 6.8-8.2, с оптимумом 7.0-7.2. При росте штамм нуждается в нитрате (нитрат калия) и не нуждается в хлориде натрия. Аэроб, факультативный анаэроб. Каталазоположительный. Оксидазоотрицательный. Штамм нуждается в восстановителе, в качестве которого использовали сульфид натрия (2.5 мМ). При более высоких концентрациях сульфида (10, 12.5 и 15 мМ) рост ухудшается, при концентрации 20-25 мМ прекращается полностью. В качестве источника энергии и углерода использует глюкозу, фруктозу, рамнозу, маннозу, мальтозу, сахарозу. Растет на агаре с эскулином, гидролизует крахмал. Для роста необходимы дрожжевой экстракт и витамины. Не использует ксилозу, арабинозу, галактозу, лактозу, рафинозу, салицин, сорбит, инозит, дульцит, адонит, цитрат, ацетат, малонат натрия, пируват, сукцинат лактат, мочевину, желатину, метанол, этанол, бутанол, пропанол.

Анализ состава жирных кислот. У большинства микроорганизмов рода Geobacillus идентифицируются насыщенные и ненасыщенные жирные кислоты с длиной цепи от 15 до 20 атомов углерода. На хроматограммах экстрактов метилированных эфиров жирных кислот (ЖК) идентифицированы 15 пиков. Из них 5 метиловых эфиров (МЭ) насыщенных жирных кислот (НЖК), 7 метиловых эфиров разветвленных НЖК, 2 метиловых эфира мононенасыщенных ЖК и один МЭ разветвленной мононенасыщенной ЖК. Анализ пиков показал преобладание метиловых эфиров жирных кислот iso-C15:0 - 33 \%; iso-C16:0 - 13.6 \%; iso-C17:0 - 32.3 \%; iso-C17:1 n-11 - 7.3 \%. Остальные жирные кислоты содержатся в минорных количествах (табл.1). Известно, что жирные кислоты определяют физико-химические свойства клеточных стенок микроорганизмов, такие как текучесть, устойчивость к температурам, гидрофобность. Разветвлённые или алициклические жирные кислоты, благодаря особенностям химического строения у грамположительных бактерий выполняют адаптивную функцию, придавая пластичность и текучесть мембране (Budnikov, 2010; Zakharova, Sukhikh, 2015).

Анализ структуры гена 16S рPHК. На основании филогенетического анализа структуры гена $16 \mathrm{~S}$ рPHK (1293 п.н.) установлено, что полученная последовательность образует отдельную кладу с некультивируемыми формами и не группируется с другими кластерами культивируемых видов рода Geobacillus (рис. 2). Для уточнения его таксономического положения, проведено сравнение штамма PB15/Grf7geо с известными представителями фенотипических групп термофильных Geobacillus. В работе использовали последовательности типовых штаммов референтных видов, отнесенных к этому роду. Процент идентичности последовательностей гена $16 \mathrm{~S}$ рPHК штамма Geobacillus sp. PB15/Grf7geо с другими последовательностями этого кластера составляет 97 \%. Наиболее близкие последовательности - некультивируемые Geobacillus sp. clone SHBZ (97 \%), Bacillales bacterium clone DR938CH110701SACH41 (97\%).

Содержание Г + Ц пар в ДНК у штамма PB15/Grf7geо - 53.0 мол. \%, что соответствует содержанию Г + Ц пар в ДНК внутри рода Geobacillus (от 42.4 до 54.5 мол. \%) (Nazina et al., 2001). 
Khanaeva, T.A. et al. (2017). Thermophilic facultative.... Acta Biologica Sibirica, 2017, 3(3), 39-46

Таблица 1. Состав метиловых эфиров жирных кислот штамма Geobacillus sp. (PB15/Grf7geo) и представителей других групп геобацилл (\% от общего содержания МЭЖК в 1 г сухой биомассы; жирным шрифтом выделены доминирующие жирные кислоты; н.д. - нет данных)

\begin{tabular}{|c|c|c|c|c|c|}
\hline $\begin{array}{l}\text { Жирная } \\
\text { кислота }\end{array}$ & $\begin{array}{c}\text { Geobacillus sp. } \\
\text { B-3150 }\end{array}$ & $\begin{array}{c}\text { Geobacillus } \\
\text { thermoleovorans } \\
15366^{\top} \\
\text { (Nazina et al., 2001) }\end{array}$ & $\begin{array}{l}\text { Geobacillus } \\
\text { thermglucosidatus } \\
\text { (Kämpfer, 1994) }\end{array}$ & $\begin{array}{c}\text { Geobacillus } \\
\text { caldoliticus } \\
\text { DSM } 405 \text { (Andersson } \\
\text { et al., 1995) }\end{array}$ & $\begin{array}{c}\text { Geobacillus } \\
\text { smithii } \\
\text { DSM } 459^{\top} \\
\text { (Andersson et } \\
\text { al., 1995) }\end{array}$ \\
\hline $14: 0$ & 0,29 & 1 & н.д. & Н.Д. & н.д. \\
\hline 14:0 & 0,27 & 1,4 & 0,6 & Н.Д. & н.д. \\
\hline 15:0 & 33 & 22,6 & 22,0 & 22,0 & 19,0 \\
\hline 15:0 & 0,23 & 2,1 & н.д. & 1,0 & н.д. \\
\hline 16:0 & 13,6 & 21,0 & 10,4 & 37,0 & 6,0 \\
\hline 16:0 & 3,49 & 11,2 & 11,6 & 5,0 & 8,0 \\
\hline $17: 0$ & 32,3 & 18,5 & 30,3 & 22,0 & 11,0 \\
\hline 17:0 & 0,29 & 1,3 & 0,8 & 1,0 & \\
\hline 17:0 & 1,0 & 4,6 & 16,6 & 8,0 & 42,0 \\
\hline 17:1 n-11 & 7,3 & н.д. & н.д. & Н.Д. & н.д. \\
\hline $18: 0$ & 0,8 & 0,9 & н.д. & 2,0 & н.д. \\
\hline 18:0 & 1,73 & 3,4 & 0,5 & Н.Д. & н.д. \\
\hline ther & 6 & 12 & 7.2 & 2 & 14 \\
\hline
\end{tabular}

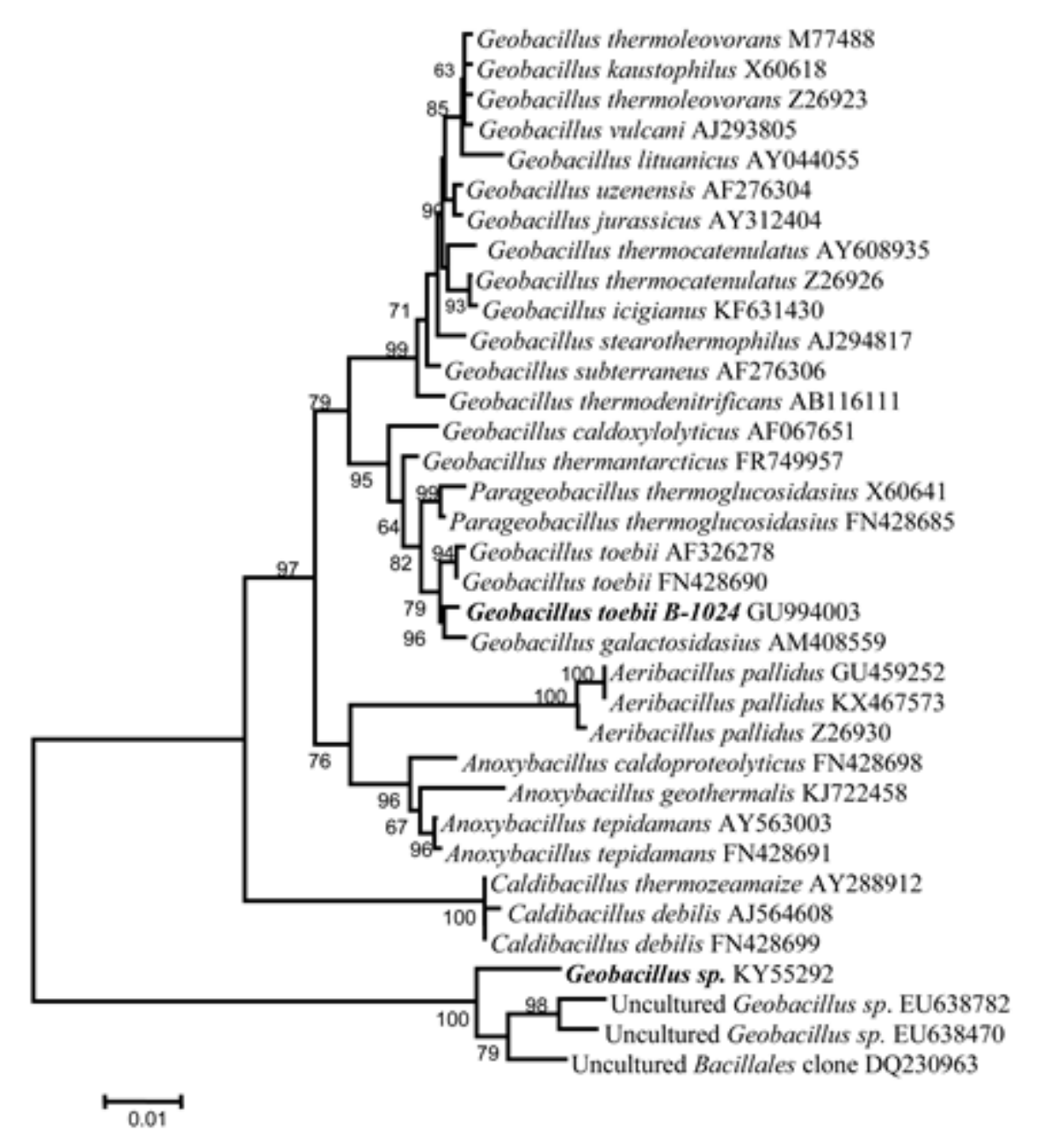

Рис 2. Филогенетическое древо нуклеотидных последовательностей гена 16S рРНК штамма Geobacillus sp. и родственных последовательностей рода Geobacillus.

Цифрами показана достоверность ветвления, установленная с помощью "bootstrap"- анализа 100 альтернативных деревьев; жирным шрифтом выделен штамм, исследованный в данной работе и штамм В-1024, который был выделен из горячих источников Байкальской рифтовой зоны (Tourova et al., 2010) 
Khanaeva, T.A. et al. (2017). Thermophilic facultative.... Acta Biologica Sibirica, 2017, 3(3), 39-46

Род Geobacillus был выделен в самостоятельный род с таксономическим описанием в 2001 г. Т.Н. Назиной с соавторами, первоначально к нему относили 6 видов термофильных бацилл, изолированных из нефтяных месторождений Западной Сибири и Казахстана (Nazina et al, 2001). B 2010-2012 годах на основании анализа фрагментов гена $16 \mathrm{~S}$ рPHК была начата новая ревизия рода. Часть видов перенесена в новые роды (Aeribacillus, Caldibacillus), ряд видов объединены в подроды (Dinsdale et al., 2011; Coorevits et al., 2012). В настоящее время род Geobacillus объединяет термофильные, пресноводные и галофильные, ацидофильные и алкалофильные бактерии, которые используют широкий спектр источников углерода для роста. Экологический диапазон геобацилл очень широк, это род-космополит. Известно, что представители рода Geobacillus обладают уникальными гемицеллюлолитическими системами, что позволяет рассматривать их в качестве потенциальных источников высокоактивных и термостабильных ферментов для эффективного гидролиза биомассы. Данные микроорганизмы также обладают высокой скоростью роста и способностью утилизировать широкий круг субстратов, включая пентасахара (Brock et al., 1978; Bonch-Osmolovskaya, 2005; Rozanov et al., 2013).

Ранее проведенные исследования состава микробных сообществ донных осадков, в приразломных областях озера Байкал (подводные грязевые вулканы, метановые сипы, залежи газовых гидратов), показали, что филум Firmicutes не является доминирующим таксоном. В исследованных библиотеках генов 16S pPHК представители этого филума составляли не более 2 \% от общего количества последовательностей (Kadnikov et al., 2012; Zemskaya et al., 2015). Лишь в поверхностных осадках метанового сипа «Посольская Банка» содержание представителей филума Firmicutes составляло 4.2 \%, в глубинных - 8.9 \% от общего количества последовательностей (Chernitsyna et al., 2016). Появление в поверхностных психрофильных осадках озера Байкал термофильных микроорганизмов р. Geobacillus может быть следствием миграции газонасыщенных минерализованных флюидов, которые увлекают с собой из глубинных в поверхностные слои осадков не только диатомовые водоросли (Klerx et al., 2003), но и жизнеспособные микроорганизмы с неизвестным метаболизмом.

Не смотря на то, что термофильный, факультативно анаэробный штамм Geobacillus sp. PB15/Grf7geo выделен из низкотемпературного биотопа, его физиолого-биохимические свойства не отличаются от свойств типовых термофильных штаммов этого рода. Вместе с тем, анализ структуры гена 16S pPHK штамма PB15/Grf7geo свидетельствует о его неполной идентичности типовым культивируемым штаммам (97 \%) и обособленном филогенетическом положении внутри кластера последовательностей типовых видов. Последние результаты являются основанием для отнесения полученного штамма к новому виду. Также очевидно, что для валидации его в качестве нового вида рода Geobacillus необходимо уточнение фенотипических признаков, в части его целлюлолитических свойств, полное филогенетическое описание, в том числе и анализ его генома. Все эти аспекты будут предметом детальных исследований в дальнейшем.

\section{Благодарности}

Авторы выражают благодарность к.б.н. Е.Н. Детковой за анализ Г+Ц состава, проведенный в лаборатории реликтовых микробных сообществ Федерального исследовательского центра «Фундаментальные основы биотехнологии» Российской академии наук. Микробиологические исследования выполнены в рамках гранта РФФИ № 16-04-00181 «Глубинные микроорганизмы донных осадков оз. Байкал...», секвенирование гена 16S рPHК выполнено в рамках темы Интеграционного проекта 4.1.2 ИНЦ CO PAH «Применение методов NGS-BD (Next Generation Sequencing - Big Data) для решения вопросов экологии».

\section{References}

Andersson, M., Laukkanen, M., Nurmiaho-Lassila, E.-L., Rainey, F.A., Niemelä, S.I., Salkinoja-Salonen, M. (1995). Bacillus thermosphaericus sp. nov., a new thermophilic ureolytic bacillus isolated from air. Systematic and Applied Microbiology, 18(2), 203-220.

Bonch-Osmolovskaya, E.A., Miroshnichenko, M.L., Lebedinsky, A.V., Chernyh, N.A., Nazina, T.N., Ivoilov, V.S., Belyaev, S.S., Boulygina, E.S., Lysov Y.P., Perov, A.N., Mirzabekov, A.D., Hippe, H., Strackebrandt, E., L'Haridon, S., Jeanthon, C. (2003). Radioisotopic, culture-based, and oligonucleotide microchip analyses of thermophilic microbial communities in a continental high-temperature petroleum reservoir. Applied and Environmental Microbiology, 69, 6143-6151.

Bonch-Osmolovskaya, E.A. (2005). Phylogenetic and metabolic diversity of thermophilic prokaryotes with different types of anaerobic respiration. Microbial diversity: current perspectives and potential application. New Delhi: International Publishing House.

Brock, T.D. (1978). Thermophilic microoganisms and life at high temperatures. US: Springer-Verlag.

Brosius, J., Ullrich, A., Paker, M.A., Gray, A., Dull, T.J., Gutell, R.R., Noller, H.F. (1981). Construction and fine mapping for recombinant plasmids containing the rrnB ribosomal RNA operon of E. coli. Plasmid, 6, 112-118.

Budnikov, G.K. (2010). Himicheskij analiz v medicinskoj diagnostike. Moscow: Nauka. (in Russian)

Chernitsyna, S.M., Mamaeva, E.V., Lomakina, A.V., Pogodaeva T.V., Galach'yants Yu.P., Bukin S.V., Pimenov N.V., Khlystov O.M., Zemskaya, T.I. (2016). Phylogenetic diversity of microbial communities of the Posolsk Bank bottom sediments, Lake Baikal. Microbiology, 85(6), 672-680. 
Khanaeva, T.A. et al. (2017). Thermophilic facultative.... Acta Biologica Sibirica, 2017, 3(3), 39-46

Coorevits, A., Dinsdale, A.E., Halke,t G., Lebbe, L., De Vos, P., Van Landschoo,t A., Logan, N.A. (2012). Taxonomic revision of the genus Geobacillus: emendation of Geobacillus, G. stearothermophilus, G. jurassicus, G. toebii, G. thermodenitrificans and G. thermoglucosidans (nom. corrig., formerly 'thermoglucosidasius'); transfer of Bacillus thermantarcticus to the genus as G. thermantarcticus comb. nov.; proposal of Caldibacillus debilis gen. nov., comb. nov.; transfer of G. tepidamans to Anoxybacillus as A. tepidamans comb. nov.; and proposal of Anoxybacillus caldiproteolyticus sp. nov. International J. Systematic and Evolutionary Microbiology, 62, 1470-1485.

Denisova, L.Ya., Belkova, N.L., Tulokhonov, I.I., Zaichikov, E.F. (1999). Bacterial diversity at various depths in the southern part of Lake Baikal as revealed by 16S rDNA sequencing. Microbiology, 68(4), 457-483.

Dinsdale, A.E., Halket, G., Coorevits, A., Van Landschoot, A., Busse, H.J., De Vos, P., Logan, N.A. (2011). Emended descriptions of Geobacillus thermoleovorans and Geobacillus thermocatenulatus. International J. Systematic and Evolutionary Microbiology, 61, 1802-1810.

Frank, Y.A., Kadnikov, V.V., Gavrilov, S.N., Banks, D., Gerasimchuk, A.L, Podosokorskaya, O.A., Merkel, A.Y., Chernyh, N.A., Mardanov, A.V., Ravin, N.V., Karnachuk, O.V. Bonch-Osmolovskaya, E.A. (2016). Stable and variable parts of microbial community in siberian deep subsurface thermal aquifer system revealed in a long-term monitoring study. Frontiers in Microbiology, 7, 2101. doi: 10.3389/fmicb.2016.02101.

Ghiorse, W.C., Wilson, J.T. (1988). Microbial ecology of the terrestrial subsurface. Advances in Applied Microbiology, 33, 107-173.

Heats, L.S., Sloan, G.L., Heath, H.E. (1986). A simple and generally applicable procedure for releasing DNA from bacterial cells. Applied and Environmental Microbiology, 51(5), 1138-1140.

Hungate, R.E. (1969). A roll tube method for the cultivation of strict anaerobes. Methods in Microbiology. US: Academic Press.

Jiménez, L. (1990). Molecular analysis of deep-subsurface Bacteria. Applied and Environmental Microbiology, 56, 21082113.

Kadnikov, V.V., Mardanov, A.V., Beletsky, A.V., Shubenkova, O.V., Pogodaeva, T.V., Zemskaya, T.I. (2012). Microbial community structure in methane hydrate-bearing sediments of freshwater Lake Baikal. FEMS Microbiology Ecology, 79, 348-358.

Kämpfer, P. (1994). Limits and possibilities of total fatty acid analysis for classification and identification of Bacillus species. Systematic and Applied Microbiology, 17(1), 86-98.

Klerx, J., Zemskaya, T.I., Matveeva, T.V., Khlystov, O.M., Namsaraev, B.B., Dagurova, O.P., Golobokova, L.P., Vorob'eva, S.S., Pogodaeva, T.V., Granin, N.G., Kalmychkov, G.V., Ponomarchuk, V.A., Shoji, H., Mazurenko, L.L., Kaulio, V.V., Solov'ev, V.A., Grachev, M.A. 2003. Methane hydrates in the surface layer of deep water Lake Baikal sediments. Doklady Akademii Nauk, 393, 1342-1346. (In Russian)

Marmur, J. (1961). A procedure for the isolation DNA from microorganisms. J. Molecular Biology, 3, $208-218$.

Logan, N.A., Berge, O., Bishop, A.H., Busse, H.-J., De Vos P., Fritze, D., Heyndrickx, M., Kämpfer, P., Rabinovitch, L., Salkinoja-Salonen, M.S., Seldin, L. Ventosa, A. (2009). Proposed minimal standards for describing new taxa of aerobic, endospore-forming bacteria. International J. Systematic and Evolutionary Microbiology, 59, 2114-2121.

Namsaraev, B.B., Zemskaya, T.I. (2000). Microbial processes of carbon circulation in bottom sediments of Lake Baikal. Novosibirsk: Geo. (in Russian)

Naudts, L., Khlystov, O., Granin, N., Chensky, A., Poort, J., De Batist, M. (2012). Stratigraphic and structural control on the distribution of gas hydrates and active gas seeps on the Posolsky Bank, Lake Baikal. Geo-Marine Letters, 32, 395-406.

Nazina, T.N., Tourova, T.P., Poltaraus, A.B., Novikova, E.V., Grigoryan, A.A., Ivanova, A.E., Lysenko, A.M., Petrunyaka, V.V., Osipov, G.A., Belyaev, S.S., \& Ivanov, M.B. (2001). Taxonomic study of aerobic thermophilic bacilli: dDescriptions of Geobacillus subterraneus gen. nov., sp. nov. and Geobacillus uzenensis sp. nov. from petroleum reservoirs and transfer of Bacillus stearothermophilus, Bacillus thermocatenulatus, Bacillus thermoleovorans, Bacillus kaustophilus, Bacillus thermog/ucosidasius and Bacillus thermodenitrificans to Geobacillus as the New combinations G. stearothermophilus, G. thermocatenulatus, G. thermoleovorans, G. kaustophilus, G. thermog/ucosidasius and G. thermodenitrificans. International Journal of Systematic and Evolutionary Microbiology, 51, 433-446.

Owen, R.J., Hill, L.R., Lapage, S.P. (1969). Determination of DNA base compositions from melting profiles in dilute buffers. Biopolymers, 7, 503-516.

Rozanov, A.S., Ivanisenko, T.V., Bryanskaya, A.V., Shekhovtsov, S.V., Logacheva, M.D., Saik, O.V., Malup, T.K., Demenkov, P.S., Goryachkovskaya, T.N., Ivanisenko, V.A., Peltek, S.E. (2014). Bioinformatic analysis of the genome of the Geobacillus stearothermophilus 22 strain isolated from the Garga hot springs, Baikal region. Russian J. Genetics: Applied Research, 4, 267-272.

Sambrook, J., First, E.F., Maniatis, T. (1989). Molecular cloning. A laboratory manual. US: Cold Spring Harbor Laboratory Press.

Takai, K., Moser, D.P., DeFlaun, M., Onstott T.C., Fredrickson, J.K. (2001). Archaeal diversity in waters from deep South African gold mines. Applied and Environmental Microbiology, 67, 5750-5760.

Tourova, T.P., Sokolova, D.S., Semenova, E.M., Shumkova, E.S., Korshunova, A.V., Babich, T.L., Nazina, T.N., Poltaraus, A.B. (2016). Detection of $n$-alkane biodegradation genes alkB and ladA in the thermophilic hydrocarbon-oxidizing bacteria of the genera Aeribacillus and Geobacillus. Microbiology, 85(6), 693-707.

Widdel, F., Back, F. (1992). The Prokaryotes. Ecophysiology and Biogeochemistry. US: Springer. 
Zakharova, Y.V., Sukhikh, A.S. (2015) Chromatographic analyses of membrane fatty acid Bifidobacterium with different hydrophobicity. Sorbchionnye I chromatographicheskie processi, 15(6), 776-783. (in Russian)

Zemskaya, T., Lomakina, A., Mamaeva, E., Zakharenko, A., Pogodaeva, T., Petrova D. (2015). Bacterial communities in sediments of Lake Baikal from areas with oil and gas discharge. Aquatic Microbial Ecology, 76, 95-109.

\section{Citation:}

Khanaeva, T.A., Pavlova, O.N., Chernitsyna, S.M., Khalzov, I.A., Khabuev, A.V., Nikonova, A.A., Novikova, A.S., Zemskaya, T. I. (2017). Thermophilic facultative anaerobic bacteria of the genus Geobacillus from bottom sediments of Lake Baikal. Acta Biologica Sibirica, 3 (3), 39-46.

Submitted: 03.06.2016. Accepted: 18.08.2017

cross ref http://dx.doi.org/10.14258/abs.v3i3.3614

(C) 2017 by the authors. Submitted for possible open access publication under the terms and conditions of the Creative Commons Attribution (CC BY) license (http://creativecommons.org/licenses/by/4.0/). 